\title{
Relevance of Children's Public Parks of Cities to the Health of Children
}

\section{Pedro Gil-Madrona* and Alejandro Prieto-Ayuso}

Department of Teaching Musical, Plastic and Corporal, Faculty of Education (Albacete), University of Castilla-La Mancha, Spain

*Corresponding author: Pedro Gil-Madrona, Department of Teaching Musical, Plastic and Corporal, Faculty of Education (Albacete), University of Castilla-La Mancha, Spain, Tel: +34926295300; E-mail: Pedro.Gil@uclm.es

Rec date: Sep 12, 2016; Acc date: Oct 03, 2016; Pub date: Oct 05, 2016

Copyright: @ 2016 Gil-Madrona P, et al. This is an open-access article distributed under the terms of the Creative Commons Attribution License, which permits unrestricted use, distribution, and reproduction in any medium, provided the original author and source are credited.

\section{Abstract}

Developed countries are facing an "epidemic" of childhood obesity. During the past four decades, the obesity rate among children between 6 and 11 years of age has increase more than quadruple within the last years. Thus, childhood obesity has become one of the greatest health problems nowadays, turning into the epidemic of the XXI century.

Keywords: Childhood obesity; Children; Physical activity; Eating habits; Prohibitions

\section{Mini Review}

Besides, one out of three children between 13 and 14 are overweight, being one of the highest rates of childhood obesity rate within Europe $[1,2]$. That is why there seems to be a combination of a sedentary lifestyle and the decrease of physical activity and the practice of sport activities which, linked to some changes in eating habits, is contributing to the emergence of an epidemic of overweight-obesity [3].

There are several studies which show the engagement of children and teenagers to physical activity for at least one hour a day $[4,5]$. Although the lack of physical activity is not the only reason to explain the fast increase of obesity among children and teenagers, we can notice that it is one of the causes of this problem [6].

The situation in which children are in big cities is increasingly distressing, and not because of the lack of spaces, as the street is theoretically the most complete place for the development of children's physical activity in the open air, but due to the fact that in cities lot of hidden dangers and prohibitions that continually threaten them. Indeed, children live in the city has been a topic of discussion and reflection [7-9].

Only at the playgrounds can children find a good place of developing their games in the open air. The parks with playground areas are extended within cities. It is difficult nowadays to find a district which doesn't have any kind of playground for children. A playground can be defined as a small area, either public or private, which is provided with equipment and furniture which facilitates the development of recreational physical activity among children. But as they are raised and designed, their usefulness is very small. Playgrounds are generally places of approximately 200 meters square with sandy floors and seven or eight fixtures, with little or no green zones. The ideal purpose is to develop complex playgrounds in the open air, with several areas provided with several fixtures, immersed within green areas which can serve as an attraction point; those playgrounds should be provided with other non-defined structures to be used by children as well, in order to help them develop their imagination; with a third extended area where green spaces play a main role [10-12].

Moreover, numerous studies have shown that outdoor games during childhood lead to positive results which could not be possible if games were developed indoors. Playing in the open air promote more active movement and a better physical development.

One research found a strong link between the number of natural features in a game environment (e.g. grass, trees, hills, water and sand) and children's level of activity [13-15]. Children develop communicative skills through motor game, and it can lead to the organization and integration of the different areas of the brain which are necessary for perception, social understanding and self-regulation.

In this regard, several studies have shown that public parks contribute to the health of the child, but understood that health as global, that is, to improve imagination, socialization, elimination of social inequalities, improving memory, processing information and other cognitive skills necessary for learning $[16,17]$. Moreover, it has been demonstrated the direct relationship between play and performance in reading and mathematics in primary education [18]. In addition, also the aptitude and emotional well-being has been investigated in this regard, concluding improving these aspects through play in public parks [18-22].

Therefore, such scientific evidence must convince policy makers to enhance and improve the playgrounds of cities.

To sum up, outdoor motor games contribute to social and cognitive development of children and they are necessary for learning [23]. For this purpose, parents and professionals of education should require the development of policies that can lead to an improvement in play opportunities so that this can become a reality for children in Europe and around the world.

\section{References}

1. De Onis M, Blössner M, Borghi E (2010) Global prevalence and trends of overweight and obesity among preschool children. The Am J Clin Nutr 92: $1257-1264$

2. OECD: Organisation for Economic Co-operation and Development (2012) Obestity and the Economic of Prevention: Fit not Fat. Available from. http://www.naos.aesan.msssi.gob.es/naos/ficheros/investigacion/ OCDE_Informe_situacion_Espana_Feb_2012.pdf. 
Citation: Gil-Madrona P, Prieto-Ayuso A (2016) Relevance of Children's Public Parks of Cities to the Health of Children. J Trauma Treat 5: 333. doi:10.4172/2167-1222.1000333

Page 2 of 2

3. Watts K, Jones TW, Davis EA, Green D (2005) Exercise training in obese children and adolescents: current concepts. J Sports Med 35: 375-392.

4. Biro FM, Wien M (2010) Childhood obesity and adult morbidities. Am J Clin Nutr 91: 1499-1505.

5. Daniels SR, Arnett DK, Eckel RH, Gidding SS, Hayman LL, et al. (2012) Overweight in children and adolescents: pathophysiology, consequences, prevention, and treatment. Circulation 111: 1999-2012.

6. Vanderwater EA (2004) Linking Obesity and Activity Level with Children's Television and Video Game Use. J Adolesc 27: 71-85.

7. Arias F, Caivano F, Calvo B, Fallon C, Gaitán L, et al. (2001) I Encuentro "The City of Children." Madrid: educational activities.

8. Cabanellas I, Eslaba C (2005) Territories childhood: Dialogues between architecture and pedagogy. Barcelona: Graó.

9. Christensen P (2003) Place, space and knowledge: Children in the village and the city. In: Christensen P, O'Brien M (coords.), Children in the city: Home, neighbourhood and community (pp. 13-28). Londres: RoutledgeFalmer.

10. Ballester-Olmos JF, Llorens B, Bravo R, Arguedas J (2009) Evaluation of accessibility of green areas. Method M.E.A.J. Valencia. Polytechnic university of Valencia.

11. Moore RC, Goltsman SM, Iacofano DS (1992) Play for All Guidelines: Planning, Design and Management of Outdoor Play Settings for All Children. Berkeley, CA: MIG Communications.

12. Moore RC, Wong HH (1997) Natural Learning: Creating Environments for Rediscovering Nature's Way of Teaching. Berkley: MIG Communications.

13. Fjørtoft I (2000) Landscape as Playscape: Learning Effects from Playing in a Natural Environment on Motor Development in Children. Doctoral Dissertation. Oslo: Norwegian University of Sport and Physical Education.
14. Fjørtoft I (2001) The Natural Environment as a Playground for Children: The Impact of Outdoor Play Activities in Pre-Primary School Children. ECEJ 29: 111-117.

15. Fjørtoft I (2004) Landscape as playscape: The effects of natural environments on children's play and motor development. Child Youth Environ 14: 21-44.

16. Pellegrini AD, Bohn CM (2005) The role of recess in children's cognitive performance and school adjustment. Educ Res 34: 13-19.

17. Piek JP, Dawson L, Smith LM, Gasson N (2008) The role of early fine and gross motor development on later motor and cognitive ability. Hum Mov Sci 27: 668-681.

18. Castelli DM, Hillman CH, Buck SM, Erwin HE (2007) Physical fitness and academic achievement in third- and fifth-grade students. J Sport Exerc Psychol 29: 239-252.

19. Tovey H (2007) Playing outdoors. Spaces and places, risk and challenge. Maidenhead: Open University Press.

20. Trawick-Smith J (2010) Drawing back the lens on play: A frame analysis of young children's play in Puerto Rico. Early Educ Dev 21: 536-567.

21. Whitebread D (2010) Play, metacognition and self-regulation. In: Broadhead P, Howard J, Wood E (Eds.). Play and learning in the early years. London: Sage.

22. Whitebread D (2011) Developmental Psychology and Early Childhood Education. London: Sage.

23. Pellegrini AD, Kato K, Blatchford P, Baines E (2002) A short-term longitudinal study of children's playground games across the first year of school: Implications for social competence and adjustment to school. Am Educ Res J 39: 991-1015. 